\section{RSP}

http://www.rsp.fsp.usp.br/
Revista de Saúde Pública

\title{
Illicit drug use among students of a university in Southern Brazil
}

\author{
Gbènankpon Mathias Houvèssou' \\ Mariângela Freitas da Silveira' \\ ' Universidade Federal de Pelotas. Faculdade de Medicina. Programa de Pós-Graduação em Epidemiologia. \\ Pelotas, RS, Brasil
}

\section{ABSTRACT}

OBJECTIVE: To describe drug consumption and the co-occurrence use of more than one illegal drug as well as associated factors in freshmen at a public university in Southern Brazil.

METHODS: Cross-sectional study with census of students entering undergraduate courses in 2017. A total of 1,788 university students answered questions about illicit drug use. For analysis, ordinal logistic regression was used.

RESULTS: Marijuana was the most consumed drug (lifetime: 42.1\%; 30-day use: 22.7\%), followed by hallucinogens (lifetime: $13.1 \%$, 30-day use: $2.8 \%$ ). Rates for lifetime use of 0 , 1 and 2 or more drugs were $56.2 \%, 23.3 \%$ and $20.4 \%$, respectively, and were associated with men $(\mathrm{OR}=2.2$; 95\%CI:1.4-3.5), being at least 23 years old (OR = 2.7; 95\%CI: 1.4-5.1), under 18 years old first experimentation with drugs (OR $=2.3$; 95\%CI: 1.3-3.9) and living with friends $(\mathrm{OR}=2.0$; 95\%CI: $1.2-3.4)$. Rates for 30 -day use of 0,1 and 2 or more drugs were $76.8 \% ; 18.1 \%$ and $5.1 \%$, respectively, and were associated with being single, separated or widowed $(\mathrm{OR}=3.2$; 95\%CI: 1.4-7.0), lower socioeconomic classes (OR $=0.3$; 95\%CI: 0.1-1.1; $\mathrm{p}=0.001$ ), under 18 years old first experimentation with drugs $(\mathrm{OR}=1.8$; 95\%CI: $1.1-2.9)$ and living with friends $(\mathrm{OR}=1.8$ 95\%CI: $1.2-2.8)$.

CONCLUSION: Results indicate that students are at greater risk of illicit drug-related health problems. Thus, a better understanding of this consumption should be pursued, as well as the development of a prevention plan.

DESCRIPTORS: Young Adult. Universities. Street Drugs. Drug-Seeking Behavior. Risk Factors.

Gbènankpon Mathias Houvèssou

Rua Marechal Deodoro, 1160

$3^{\circ}$ piso - Centro

Caixa Postal 464

96020-220 Pelotas, RS, Brasil

E-mail: gbemathg@gmail.com

Received: Nov 01, 2019

Approved: Jan 09, 2020

How to cite: Houvèssou GM, Bierhals IO, Flesch BD, Silveira MF. Illicit drug use among students of a university in Southern Brazil. Rev

Saude Publica. 2020;54:57.

Copyright: This is an open-access article distributed under the terms of the Creative Commons Attribution License, which permits unrestricted use, distribution, and reproduction in any medium, provided that the original author and source are credited. 


\section{INTRODUCTION}

It is estimated that 275 million people worldwide, approximately $5.6 \%$ of the world's population aged between 15 and 64, used drugs at least once in 2016. Between 2000 and 2015 , deaths due to drug use increased over 60\%, of which approximately 168,000 were directly associated with drug-induced disorders (mainly overdoses). Furthermore, about 31 million people who used drugs suffered from use-related disorders ${ }^{1}$.

The university period is characterized by independence and distancing from parental supervision. In addition, it also features a transition period, including different living conditions from those of childhood and adolescence, new experiences, new bonds of friendship and family pressure ${ }^{2}$. Experimentation with illicit drug use at this stage is evident worldwide ${ }^{2-5}$, and the use of these substances within this period may increase ${ }^{6}$. Thus, undesirable results are a public health concern ${ }^{7}$, including unsafe $\operatorname{sex}^{3}$, depression ${ }^{8}$, poor academic performance ${ }^{5}$ and dropouts ${ }^{8}$.

In the United States, a national survey monitored the prevalence of drug use among students for 30 years, from eighth grade to adulthood, especially during the university phase ${ }^{9}$. Findings showed that $18.9 \%$ of university students admitted to using an illicit drug in the last 30 days, exceeding the $8 \%$ prevalence for the general population aged between 12 to $65^{9,10}$. In Brazil, according to the 2009 "First national survey on the use of alcohol, tobacco and other drugs among university students from 27 Brazilian capitals", almost half of university students (48.7\%) reported having used some illicit drug at least once in their lives, of which approximately one third (35.8\%) had done so in the last 12 months and a quarter (25.9\%) in the last 30 days. The most commonly used drugs within the 12 months before the survey were: marijuana (13.8\%), amphetamines (10.5\%), tranquilizers (8.4\%), inhalants (6.5\%) and hallucinogens (5\%). Similarly, most frequently consumed drugs within the 30 days before the survey were: marijuana (9.1\%), amphetamines (8.7\%), tranquillizers (5.8\%), inhalants $(2.9 \%)$ and hallucinogens $(2.8 \%)^{11}$.

Numerous social-, demographic-, economic- and family-related factors in this population are associated with substance use. Among many coexisting risk factors, there were: being male ${ }^{12-16}$, having a higher family income ${ }^{16}$, presenting other lifestyle characteristics and risk behaviors such as smoking and alcohol consumption ${ }^{3-4}$, and living with friends or people who use drugs ${ }^{14}$. On the other hand, protective factors included religious practice and living with relatives ${ }^{3,4}$, family communication ${ }^{17}$ and commitment to education ${ }^{18}$.

Due to the potential damage on physical and mental health, acknowledging university students simultaneous consumption of more than one illicit drug has become increasingly important $^{19}$. Although many studies have evaluated illicit drug use in this population ${ }^{14,15,20-23}$, the simultaneous use of more than one substance has not been thorough studied. Thus, our study aimed to describe drug consumption among university students and evaluate the co-occurrence consumption of more than one illicit drug, including associated factors.

\section{METHODS}

Using a census format, this cross-sectional university-based study was conducted with undergraduate students enrolled at the Universidade Federal de Pelotas (UFPel) in 2017 to determine this population's health characteristics. This was a census study conducted by the UFPel Graduate Epidemiology Program and is part of the University Student Health - UFPel (SEU) research consortium. UFPel is located in the south of Rio Grande do Sul and was created in 1969. It has 96 presential courses, receiving about 3,000 new students each semester. In 2018, the University had 16,461 undergraduate students (http: // portal. ufpel.edu.br/historico).

A previously tested digital version of the questionnaire was developed in the REDCap (Research Electronic Data Capture) system ${ }^{24}$. The questionnaire consisted of two blocks: 
general and specific. The general block included questions regarding the subject's general data such as sex, age, major, socioeconomic level, marital status, etc. The specific block included questions of interest, such as drug consumption. The questionnaire was anonymous and self-applied using tablets.

Data were collected from November 2017 to May 2018. To facilitate student recruitment, the University provided information to all 2017 first-semester students. Course coordinators and professors were contacted to reserve time so students could answer the questionnaire, which took approximately 40 minutes. Teams of master's students were allocated in each classroom to answer the students' questions.

All students enrolled in UFPel degree programs for the first semester of 2017, either in their second or third semesters at the time of the interview, and aged 18 years or older were considered eligible for the study. So, as the study consisted of a census, every student who entered any degree program in 2017 and was still attending the course during data collection was invited to answer the survey. Those enrolled in distance learning programs or who had a visual or hearing impairment or any other condition preventing them from responding to the questionnaire were considered ineligible.

Dependent variables included use of cocaine, solvents and inhalants (loló/lança-perfume [chloroform and ether base], rubber cement, paint thinner, benzene, nail polish, gasoline), ecstasy (MDMA), hallucinogens (LSD, mushroom or lily tea) and marijuana. The questionnaire was based on the II Second National Survey on Drugs and Alcohol ${ }^{25}$, whose questions evaluated both lifetime and 30 days prior consumption categorized into the following rates: 0 = no use, 1 = used one drug, $2+=$ used two or more drugs.

Independent variables were: sex (female, male); age (18-19, 20-22, and $\geq 23$ years), used to avoid categories with very few individuals; skin color (white, black/brown/other); marital status (married or single/separated/widowed); religious practice (yes, no); living situation (with family/partner, alone, with friends); socioeconomic level (based on Brazilian Association of Research Companies [Abep] criteria: classes A, B, C, D and E) ${ }^{26}$; major depression (based on the Patient Health Questionnaire-9, with a cutoff point of $\geq 9$ ) ${ }^{27}$ stressful events (including giving up or postponing important moments of leisure, having financial problems or feeling worried, anxious, discouraged, or tense because of the academic activities; feeling alone or lacking support; suffering discrimination from peers or professors; being pressured to perform well; being verbally or physically assaulted by peers; experiencing conflict with professor(s); undergoing changes in living habits; being disappointed with teaching quality), scored on the following scale: happened, but did not affect me; happened, but I was little affected; happened, and I was partially affected; happened and deeply affected me; did not happen to me. The last variable was dichotomized later, with stressor events coded as "yes" only in cases in which participants reported having been deeply affected by at least one event; area of major (exact sciences and soil sciences/agronomy, health and biological sciences, applied social sciences and humanities, linguistics, arts and languages), morning or evening classes, and age of first experience with alcohol, tobacco or drugs ( $<18$ or $\geq 18$ years).

Statistical analyses were performed using Stata $12.1^{\circ}$ (Stata Corp., College Station, Texas, USA). Initially, a descriptive analysis of independent variables and outcomes was performed. For associations between them, ordinal logistic regression was used to provide the crude and adjusted odds ratios and their respective 95\% confidence intervals (95\%CI). Possible confounding factors were analyzed following a conceptual model, and variables considered relevant were included in the bivariate analysis.

The study was approved by the UFPel Ethics Committee of Faculdade de Medicina (Protocol No. 79250317.0.0000.5317). The study was explained, including assurances of secrecy and confidentiality, to all participants, who signed an informed consent form. 


\section{RESULTS}

A total of 2,706 students were considered eligible for the survey. After successive contact attempts, there were 792 losses and 49 denials, comprising $31.1 \%$ of the total sample. Among these, $52.8 \%$ were men, $46.7 \%$ were 23 years old or older, and $38.3 \%$ were exact sciences and soil sciences/agronomy majors. The final sample comprised 1,865 students, of which 77 did not present complete information on illicit drug issues and were excluded from the analyses. There were 1,788 participants remaining, of whom $54.6 \%$ were women, and $72.2 \%$ reported being white (Table 1 ). Most of them were among the $18-22$ age range $(74.1 \%)$, with a mean age of 22.2 years ( \pm 6.6 years). A total of $91.4 \%$ of the participants were either single, separated or widowed, and $59.2 \%$ were from the two highest social classes (A and B). Approximately $68.2 \%$ reported no religious practice, $61.8 \%$ lived with family members or partners, $55.5 \%$ presented depression symptoms, and $14.7 \%$ had undergone a stressful event. Regarding major, $34.5 \%$ were enrolled in applied social sciences and humanities courses, and the majority (53.6\%) studied during the morning.

Figure shows the prevalence of lifetime and 30-day drug use and consumption rates. Lifetime rates for 0,1 and 2 or more drugs were $56.2 \%, 23.3 \%$ and $20.4 \%$, respectively; 30 -day use rates for 0,1 and 2 or more drugs were $76.8 \%, 18.1 \%$ and $5.1 \%$, respectively. Marijuana was the most frequently used drug, with lifetime and 30-day use rates of $42.1 \%$ and $22.7 \%$, respectively, followed by hallucinogens (lifetime: 13.1\%; 30-day use: $2.8 \%$ ). The least common drugs were solvents and inhalants (lifetime use: $9.9 \%$; 30-day use: $1.5 \%$ ) and cocaine (lifetime: 9.9\%; 30-day use: 1.8\%) (Figure).

Table 2 describes factors associated with lifetime drug use rates. After adjustment for possible confounding factors, men were 2.2 times more likely (95\%CI: 1.4-3.5) to be in a higher drug consumption category than women $(\mathrm{p}=0.001)$, and individuals aged 23 years or older were 2.7 times more likely (95\%CI: 1.4-5.1) to be in a higher consumption category than 18 to 19-year-olds ( $\mathrm{p}=0.003$ ). Those who first experimented with drugs before the age of 18 were 2.3 times more likely $(95 \% \mathrm{CI}$ : $1.3-3.9)$ to be in a higher consumption category than those who first experimented with drugs at 18 or older $(p=0.003)$. Those who reported experimenting drugs with friends were twice as likely (95\%CI: 1.2-3.4) to be in a higher drug consumption category than those who lived with relatives or partners $(p=0.020)$.

Table 3 shows factors associated with 30-day drug use rates. Individuals who were single, separated or widowed were 3.2 times more likely (95\%CI: 1.4-7.0) to be in a higher consumption category than those married or in stable union $(\mathrm{p}=0.005)$. Regarding socioeconomic level, those in class B and C had 0.5 (95\%CI: 0.3-0.8) and 0.3 (95\%CI: 0.2-0.5) times less chance, respectively, than those in class A $(p=0.001)$ to be in a higher consumption category. Those who experimented with drugs before the age of 18 were 1.8 times more likely (95\%CI: 1.1-2.9) to be in a higher drug consumption category than those who did so at 18 or older ( $p=0.019)$, as were those who reported living with friends (95\%CI: 1.2-2.8) compared with those living with relatives or partners $(p=0.026)$.

\section{DISCUSSION}

This study described the consumption of illicit drugs among university students and assessed consumption rates, as well as their associated factors. Marijuana was the illicit drug most commonly consumed by students, followed by hallucinogens. Regarding associated factors, being male, 23 years old or older, having experimented with drugs before the age of 18 and living alone or with friends were risk factors for lifetime drug use; being single, separated or widowed, having higher income, and having experimented with drugs before the age of 18 were risk factors for consumption in the 30 days prior to the interview.

Rates used in this study described the prevalence of having used no drugs, at least one drug and two or more drugs. Pilatti et al. ${ }^{20}$ (2013) found a 33.3\% lifetime prevalence for using 
Table 1. Demographic, socioeconomic, behavioral, and academic profile of university students aged 18 years or older. Pelotas, Brazil, $2018(n=1,788)$.

\begin{tabular}{|c|c|c|}
\hline Variable & $n$ & $\%$ \\
\hline \multicolumn{3}{|l|}{ Sex } \\
\hline Female & 975 & 54.6 \\
\hline Male & 811 & 45.4 \\
\hline \multicolumn{3}{|l|}{ Age (years) } \\
\hline $18-19$ & 738 & 41.6 \\
\hline $20-22$ & 578 & 32.5 \\
\hline 23 or older & 460 & 25.9 \\
\hline \multicolumn{3}{|l|}{ Self-reported skin color } \\
\hline White & 1289 & 72.2 \\
\hline Black/Brown/Other & 497 & 27.8 \\
\hline \multicolumn{3}{|l|}{ Marital status } \\
\hline Married or in consensual union & 153 & 8.6 \\
\hline Single/Separated/Divorced/Widowed & 1635 & 91.4 \\
\hline \multicolumn{3}{|l|}{ Socioeconomic class (Abep criterion) } \\
\hline A & 254 & 14.8 \\
\hline B & 759 & 44.4 \\
\hline $\mathrm{C}$ & 623 & 36.4 \\
\hline $\mathrm{D} / \mathrm{E}$ & 75 & 4.4 \\
\hline \multicolumn{3}{|l|}{ Religion } \\
\hline No & 1221 & 68.3 \\
\hline Yes & 566 & 31.7 \\
\hline \multicolumn{3}{|l|}{ Depressive symptoms (PHQ9 $\geq 9$ ) } \\
\hline No & 796 & 44.5 \\
\hline Yes & 992 & 55.5 \\
\hline \multicolumn{3}{|l|}{ Exposure to stressful event } \\
\hline No & 1525 & 85.3 \\
\hline Yes & 263 & 14.7 \\
\hline \multicolumn{3}{|l|}{ Academic major } \\
\hline Exact sciences and soil/agricultural sciences & 523 & 29.3 \\
\hline Health and life sciences & 312 & 17.4 \\
\hline Applied social sciences and humanities & 617 & 34.5 \\
\hline Linguistics/arts and letters & 336 & 18.8 \\
\hline \multicolumn{3}{|l|}{ Class time } \\
\hline Morning & 959 & 53.6 \\
\hline Evening & 829 & 46.4 \\
\hline \multicolumn{3}{|l|}{ Living arrangement } \\
\hline With family or spouse/companion & 1104 & 61.8 \\
\hline Alone & 222 & 12.4 \\
\hline With friends & 460 & 25.8 \\
\hline \multicolumn{3}{|l|}{ Age at first alcohol intake } \\
\hline$<18$ & 1463 & 81.8 \\
\hline$\geq 18$ & 325 & 18.2 \\
\hline \multicolumn{3}{|l|}{ Age at first tobacco use } \\
\hline$<18$ & 305 & 64.2 \\
\hline$\geq 18$ & 170 & 35.8 \\
\hline \multicolumn{3}{|l|}{ Age at first illicit drug use } \\
\hline$<18$ & 398 & 52.0 \\
\hline$\geq 18$ & 368 & 48.0 \\
\hline
\end{tabular}




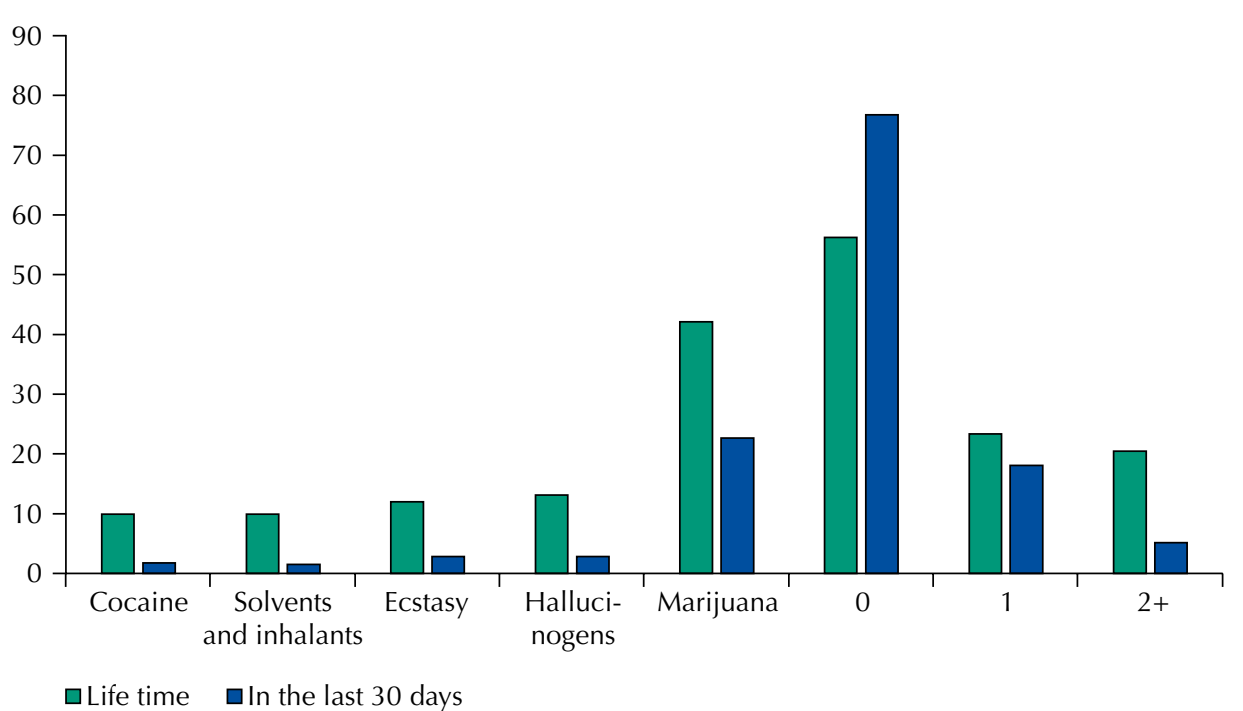

Figure. Prevalence of drug use among university students aged 18 or older in lifetime and 30 days before the survey, Pelotas, RS, 2018.

at least one drug (marijuana, cocaine, inhalant or ecstasy) and a 17.4\% 30-day prevalence. Although 30-day use prevalence were similar to that found in this study, our lifetime use prevalence was higher. ${ }^{20}$ As a higher prevalence could be expected, considering the study population was first to fifth year university students, ${ }^{20}$ one possible justification would be that Pilatti et al..$^{20}$ (2013) did not evaluate hallucinogens, the second most commonly used drug in this study. Andrade et al. ${ }^{12}$ (2012) interviewed university students nationwide from all years and found $48.7 \%$ lifetime prevalence for the use of one drug and $25.9 \%$ for 30 -day use, slightly higher than those observed in our study. This could be due to the fact that these authors included more drug varieties than this study did (as amphetamines, anticholinergics, tranquilizers, opioid analgesics, barbiturates, anabolic androgenic steroids), as well as that students were evaluated in later university years.

Although many studies have reported marijuana as the most commonly used illicit drug by university students ${ }^{14,16,20,22}$, others reported inhalants and solvents to be the most common ${ }^{13,28}$. A nationwide Brazilian study found a lower prevalence of marijuana use (26.1\% lifetime; 9.1\% 30-day use), as well as lower lifetime prevalence for all other drugs except inhalants, whose prevalence was substantially higher (20.4\%) than that of this study ${ }^{11}$. Canuto et al. ${ }^{13}$ (2006) analyzed first-year Brazilian university students, finding greater lifetime inhalant consumption $(23.0 \%)^{13}$. The highest prevalence for this substance was associated with bars/nightclubs consumption and obtaining the substance with friends, suggesting that its use occurs in a recreational context $\mathrm{t}^{13}$.

In our study, the age of first drug experimentation and the student's living situation were associated with both outcomes (lifetime and 30-day use rates). First experimentation before 18 years old increased the chance of being in a higher consumption category than first experimentation after 18 years old ( $p=0.003$ for lifetime and $p=0.019$ for 30 -day rates). Other studies have found similar results, indicating that the risk of abusing or developing an addiction to illicit drugs is greater for individuals who begin using it during adolescence rather than in adulthood ${ }^{29,30}$. For example, a 2012 United States study with adults being treated for drug dependence found that of those who first experimented with marijuana at 14 years old or younger, $13.2 \%$ were classified as addicted, six times higher than the rate of adults who first experimented with it at 18 years old or older ${ }^{31}$.

Regarding living situation, individuals living alone or with friends were more likely to be in a higher drug consumption category than those living with relatives or partners $(p=0.020$ for lifetime and $p=0.026$ for 30 -day rates), corroborating the literature ${ }^{14}$. Living outside family care is reported as a facilitator of health risk behaviors. Individuals who leave their 
Table 2. Factors associated with lifetime drugs use rate $(0,1,2+)$ among university students aged 18 or older.

\begin{tabular}{|c|c|c|c|c|c|c|c|}
\hline \multirow{2}{*}{ Level } & \multirow{2}{*}{ Variable } & \multicolumn{3}{|c|}{ Crude analysis } & \multicolumn{3}{|c|}{ Adjusted analysis } \\
\hline & & OR & $95 \% \mathrm{Cl}$ & p-value & OR & $95 \% \mathrm{CI}$ & p-value \\
\hline \multirow[t]{3}{*}{1} & Sex & & & $<0.001$ & & & 0.001 \\
\hline & Female & 1 & & & 1 & & \\
\hline & Male & 1.5 & $1.2-1.8$ & & 2.2 & $1.4-3.5$ & \\
\hline \multirow[t]{4}{*}{1} & Age (years) & & & 0.003 & & & $0.003 *$ \\
\hline & $18-19$ & 1 & & & 1 & & \\
\hline & $20-22$ & 1.4 & $1.1-1.7$ & & 1.3 & $0.7-2.2$ & \\
\hline & 23 or older & 1.3 & $1.1-1.7$ & & 2.7 & $1.4-5.1$ & \\
\hline \multirow[t]{3}{*}{1} & Self-reported skin color & & & 0.141 & & & 0.061 \\
\hline & Black/Brown/Other & 1 & & & 1 & & \\
\hline & White & 1.2 & $0.9-1.4$ & & 1.2 & $0.9-1.4$ & \\
\hline \multirow[t]{3}{*}{2} & Marital status & & & 0.294 & & & - \\
\hline & Married or in consensual union & 1 & & & - & & \\
\hline & Single/Separated/Divorced/Widowed & 1.2 & $0.9-1.7$ & & - & -- & \\
\hline \multirow[t]{5}{*}{2} & Socioeconomic class (Abep criterion) & & & 0.078 & & & 0.077 \\
\hline & A & 1 & & & 1 & & \\
\hline & B & 0.8 & $0.6-1.0$ & & 0.8 & $0.6-1.0$ & \\
\hline & $\mathrm{C}$ & 0.7 & $0.6-10$ & & 0.7 & $0.5-1.0$ & \\
\hline & $\mathrm{D} / \mathrm{E}$ & 0.6 & $0.3-0.9$ & & 0.6 & $0.3-0.9$ & \\
\hline \multirow[t]{3}{*}{3} & Religion & & & $<0.001$ & & & 0.446 \\
\hline & No & 2.1 & $1.7-2.5$ & & 1.2 & $0.7-2.2$ & \\
\hline & Yes & 1 & & & 1 & & \\
\hline \multirow[t]{3}{*}{3} & Depressive symptoms (PHQ9 $\geq 9$ ) & & & $<0.001$ & & & 0.757 \\
\hline & No & 1 & & & 1 & & \\
\hline & Yes & 1.7 & $1.4-2.0$ & & 0.9 & $0.6-1.5$ & \\
\hline \multirow[t]{3}{*}{3} & Exposure to stressful event & & & 0.722 & & & - \\
\hline & No & 1 & & & - & & \\
\hline & Yes & 1.0 & $0.8-1.3$ & & - & - & \\
\hline \multirow[t]{3}{*}{3} & Age at first alcohol intake & & & $<0.001$ & & & 0.506 \\
\hline & $<18$ & 3.6 & $2.7-4.7$ & & 1.4 & $0.6-3.3$ & \\
\hline & $\geq 18$ & 1 & & & 1 & & \\
\hline \multirow[t]{3}{*}{3} & Age at first tobacco use & & & $<0.001$ & & & 0.050 \\
\hline & $<18$ & 2.3 & $1.6-3.2$ & & 1.7 & $0.9-2.9$ & \\
\hline & $\geq 18$ & 1 & & & 1 & & \\
\hline \multirow[t]{3}{*}{3} & Age at first illicit drug use & & & $<0.001$ & & & 0.003 \\
\hline & $<18$ & 2.7 & $2.0-3.7$ & & 2.3 & $1.3-3.9$ & \\
\hline & $\geq 18$ & 1 & & & 1 & & \\
\hline \multirow[t]{5}{*}{3} & Academic major & & & $<0.001$ & & & 0.329 \\
\hline & Exact sciences and soil/agricultural sciences & 1 & & & 1 & & \\
\hline & Health and life sciences & 1.3 & $1.0-1.8$ & & 2.0 & $0.9-4.2$ & \\
\hline & Applied social sciences and humanities & 1.3 & $1.0-1.6$ & & 1.3 & $0.7-2.7$ & \\
\hline & Linguistics/arts and letters & 1.7 & $1.3-2.3$ & & 1.4 & $0.8-3.1$ & \\
\hline \multirow[t]{3}{*}{4} & Class time & & & 0.012 & & & 0.480 \\
\hline & Morning & 1 & & & 1 & & \\
\hline & Evening & 1.3 & $1.0-1.5$ & & 1.2 & $0.7-1.9$ & \\
\hline \multirow[t]{4}{*}{4} & Living arrangement & & & $<0.001$ & & & 0.020 \\
\hline & With family or spouse/companion & 1 & & & 1 & & \\
\hline & Alone & 1.4 & $1.1-1.9$ & & 2.0 & $0.9-3.9$ & \\
\hline & With friends & 2.6 & $2.1-3.2$ & & 2.0 & $1.2-3.4$ & \\
\hline
\end{tabular}

Level 1: adjusted for sex, age, self-reported skin color; Level 2: previous adjustment + socioeconomic class; Level 3: previous adjustment + religion, depressive symptoms, age at first alcohol intake, age at first tobacco use, age at first illicit drugs use and academic major; Level 4: previous adjustment + class time and living arrangement.

$*$ p-value of linear tendency 
Table 3. Factors associated with the 30 days before drugs use rate $(0,1,2+)$ among university students aged 18 or older.

\begin{tabular}{|c|c|c|c|c|c|c|c|}
\hline \multirow{2}{*}{ Level } & \multirow{2}{*}{ Variable } & \multicolumn{3}{|c|}{ Crude analysis } & \multicolumn{3}{|c|}{ Adjusted analysis } \\
\hline & & OR & $95 \% \mathrm{Cl}$ & p-value & OR & $95 \% \mathrm{Cl}$ & p-value \\
\hline \multirow[t]{3}{*}{1} & Sex & & & 0.039 & & & 0.559 \\
\hline & Female & 1 & & & 1 & & \\
\hline & Male & 1.3 & $1.0-1.6$ & & 1.1 & $0.7-1.7$ & \\
\hline \multirow[t]{4}{*}{1} & Age (years) & & & 0.250 & & & - \\
\hline & $18-19$ & 1 & & & - & & \\
\hline & $20-22$ & 1.0 & $0.8-1.3$ & & - & - & \\
\hline & 23 or older & 0.8 & $0.6-1.1$ & & - & - & \\
\hline \multirow[t]{3}{*}{1} & Self-reported skin color & & & 0.506 & & & - \\
\hline & Black/Brown/Other & 1 & & & - & & \\
\hline & White & 1.1 & $0.9-1.4$ & & - & - & \\
\hline \multirow[t]{3}{*}{2} & Marital status & & & $<0.001$ & & & 0.005 \\
\hline & Married or in consensual union & 1 & & & 1 & & \\
\hline & Single/Separated/Divorced/Widowed & 2.2 & $1.3-3.5$ & & 3.2 & $1.4-7.0$ & \\
\hline \multirow[t]{5}{*}{2} & Socioeconomic class (Abep criterion) & & & 0.040 & & & 0.001 \\
\hline & A & 1 & & & 1 & & \\
\hline & B & 0.9 & $0.6-1.2$ & & 0.5 & $0.3-0.8$ & \\
\hline & $\mathrm{C}$ & 0.7 & $0.5-0.9$ & & 0.3 & $0.2-0.5$ & \\
\hline & $\mathrm{D} / \mathrm{E}$ & 0.6 & $0.3-1.2$ & & 0.3 & $0.1-1.1$ & \\
\hline \multirow[t]{3}{*}{3} & Religion & & & $<0.001$ & & & 0.874 \\
\hline & No & 1.9 & $1.5-2.9$ & & 0.9 & $0.6-1.5$ & \\
\hline & Yes & 1 & & & 1 & & \\
\hline \multirow[t]{3}{*}{3} & Depressive symptoms (PHQ9 $\geq 9$ ) & & & $<0.001$ & & & 0.411 \\
\hline & No & 1 & & & 1 & & \\
\hline & Yes & 1.7 & $1.3-2.1$ & & 1.2 & $0.8-1.9$ & \\
\hline \multirow[t]{3}{*}{3} & Exposure to stressful event & & & 0.166 & & & 0.732 \\
\hline & No & 1 & & & 1 & & \\
\hline & Yes & 1.2 & $0.9-1.7$ & & 1.1 & $0.6-1.8$ & \\
\hline \multirow[t]{3}{*}{3} & Age at first alcohol intake & & & $<0.001$ & & & 0.109 \\
\hline & $<18$ & 3.4 & $2.3-5.0$ & & 1.9 & $0.9-4.3$ & \\
\hline & $\geq 18$ & 1 & & & 1 & & \\
\hline \multirow[t]{3}{*}{3} & Age at first tobacco use & & & 0.117 & & & 0.094 \\
\hline & $<18$ & 1.3 & $0.9-1.9$ & & 0.7 & $0.4-1.1$ & \\
\hline & $\geq 18$ & 1 & & & 1 & & \\
\hline \multirow[t]{3}{*}{3} & Age at first illicit drug use & & & $<0.001$ & & & 0.019 \\
\hline & $<18$ & 1.8 & $1.3-2.3$ & & 1.8 & $1.1-2.9$ & \\
\hline & $\geq 18$ & 1 & & & 1 & & \\
\hline \multirow[t]{5}{*}{3} & Academic major & & & 0.005 & & & 0.557 \\
\hline & Exact sciences and soil/agricultural sciences & 1 & & & 1 & & \\
\hline & Health and life sciences & 1.1 & $0.8-1.5$ & & 1.6 & $0.8-3.1$ & \\
\hline & Applied social sciences and humanities & 1.2 & $0.9-1.6$ & & 1.5 & $0.8-2.8$ & \\
\hline & Linguistics/arts and letters & 1.7 & $1.3-2.4$ & & 1.3 & $0.7-2.5$ & \\
\hline \multirow[t]{3}{*}{4} & Class time & & & 0.573 & & & - \\
\hline & Morning & 1 & & & - & & \\
\hline & Evening & 1.1 & $0.9-1.3$ & & - & - & \\
\hline \multirow[t]{4}{*}{4} & Living arrangement & & & $<0.001$ & & & 0.026 \\
\hline & With family or spouse/companion & 1 & & & 1 & & \\
\hline & Alone & 1.9 & $1.4-2.7$ & & 1.7 & $0.9-3.2$ & \\
\hline & With friends & 3.2 & $2.5-4.1$ & & 1.8 & $1.2-2.8$ & \\
\hline
\end{tabular}

Level 1: adjusted for sex, socioeconomic class, marital status; level 2: previous adjustment + religion, depressive symptoms, stressful event, age at first alcohol intake, age at first tobacco use, age at first illicit drug use and academic major; level 3: previous adjustment + living arrangement. 
parents' home to study and remain far from them, for instance, may have a greater sense of freedom towards new experiences and curiosities, such as the use of licit and illicit drugs ${ }^{32}$.

Regarding lifetime drug use rates, sex $(p=0.001)$ and age $(p=0.003)$ were also associated variables. Men were more likely to be in a higher drug consumption category than women. This finding could be explained by the fact that women perceive drugs as more dangerous ${ }^{33}$. It may also reflect a greater social tolerance for men who use drugs and a greater social stigma for women ${ }^{33}$. Biologically speaking, drug metabolism is different in men and women, with men generally having higher clearance rates ${ }^{34}$. A similar result was found by Silva et al. ${ }^{16}$ (2006) and McCabe et al. ${ }^{35}$ (2007), who assessed 12-month illicit drug use. Nevertheless, sex was not associated with 30-day use rates in this study adjusted analysis $(\mathrm{p}=0.559)$.

In our study, age increase is proportional to the increase in chances of being in a higher drug consumption category, corroborating Passos et al. ${ }^{23}$ (2006), who evaluated young people, mostly between 17 and 23 years old and found that as age increases, so does illicit drug use $^{23}$. Despite the trend found in this study and that of Passos ${ }^{23}$ et al., involving very similar age groups, nearly all included individuals were between 18 and 24 years old, age group of greatest drug consumption ${ }^{36}$. A study on young American adults between 18 and 29 years old found that this group has higher rates for drug use, abuse and dependence than older age groups $^{37}$. The difference between the results of the present study and these of Johnston et. al ${ }^{37}$ could be due to the fact that after young adulthood some social responsibilities (adult roles) are assumed, such as having children, and the use of illicit drugs decreases ${ }^{38}$.

Marital status and socioeconomic level were associated with 30-day use rates. Higher illicit drug use was observed among single, separated and widowed individuals $(\mathrm{p}=0.005)$. A longitudinal study by Duncan et $\mathrm{al}^{39}$. (2006) that assessed the effects of marriage and cohabitation on drug use, reported a decrease in the consumption of marijuana among married couples, presenting a protective effect against drug use ${ }^{39}$. Thus, it has been observed that socially deviant behavior, such as illicit drug use, are incompatible with traditional adult social roles, such as marriage ${ }^{38}$, which could justify the finding of the present study that single individuals consume more drugs.

Socioeconomic level was associated with 30-day drug use, in which individuals with higher incomes presented higher consumption $(\mathrm{p}=0.001)$. Other studies found similar results $^{16,40}$. This was also consistent with the findings of Humensky $(2010)^{40}$, who evaluated the relationship between adolescent socioeconomic status and 30-day drug use in early adulthood. Among people whose parents had higher incomes, a higher use of marijuana and cocaine was found ${ }^{40}$, implying that illicit substances demand is price sensitive ${ }^{41}$, This finding can be firstly explained by the fact that it is easier for students with higher incomes to acquire drugs ${ }^{42}$ and, secondly because parents with higher incomes generally have a greater commitment to work, contributing less to the monitoring of their children's behavior ${ }^{43}$. A study by Martins et. $\mathrm{al}^{44}$ (2008) supports this argument by indicating that parental monitoring or positive parenting practices reduce the risk of adolescent drug use and abuse ${ }^{44}$. Finally, students of lower economic classes tend to consider university education a path to social mobility ${ }^{45}$, whereas richer students celebrate youth by socializing and engaging in deviant behaviors ${ }^{45}$.

This study has some limitations. Due to the cross-sectional design, the main limitation of the study is a possible reverse causality bias in some associations, such as the marital status variable. Losses to follow-up and refusals were significant, restricting findings extrapolation, with a greater conflict among men, students aged 23 and older, and students of exact sciences and soil/agricultural science programs; which may have led to selection bias. Students not reached could have presented higher drug use, leading to difficulties to attend classes and a greater possibility of abandoning university studies. In addition, as losses were greater among men and students of exact sciences and soil/agricultural sciences, also those with a greater chance of using any substance, the prevalence found could be underestimated. Some students may have preferred not to report illicit drug use, even with guaranteed anonymity. 
Thus, drug use prevalence should be interpreted as minimum estimates of the actual values, which could be higher. However, using a self-administered confidential questionnaire is a standard procedure for obtaining information about this type of behavior. Another limitation is the generalization of the findings to the entire university population, since only new students were included in the study population. As it was performed in a consortium format, the number of questions in the study was also limited, preventing a more detailed outcome assessment, such as when drug experimentation first occurred and situations and places where drugs were consumed. The long duration of data collection is also one of the limitations of this study. Students who were interviewed at the end of fieldwork are more exposed to the university environment than those who were interviewed at the beginning.

The study has some strengths, as it contributes to the comprehension of the use of illegal drugs and its associated factors among university students.

In conclusion, marijuana was the most frequently illicit drug used by students, and $5.1 \%$ of the participants reported using two or more illicit drugs in the 30 days before the survey, representing the group at highest risk of dependence and possible psychological distress. Our results are expected to contribute to a better understanding of the context of substance use in this population.

\section{REFERENCES}

1. United Nations Office on Drugs and Crime. World Drug Report 2018: global overview of drug demand and supply. Vienna: UNODC; 2018.

2. Sommet A, Ferrières N, Jaoul V, Cadieux L, Soulat JM, Lapeyre-Mestre M, et al. Use of drugs, tobacco, alcohol and illicit substances in a French student population. Therapie. 2012;67(5):429-35. https://doi.org/10.2515/therapie/2012056

3. Mohammadpoorasl A, Ghahramanloo AA, Allahverdipour H, Augner C. Substance abuse in relation to religiosity and familial support in Iranian college students. Asian J Psychiatr. 2014;9:41-4. https://doi.org/10.1016/j.ajp.2013.12.015

4. Suerken CK, Reboussin BA, Sutfin EL, Wagoner KG, Spangler J, Wolfson M. Prevalence of marijuana use at college entry and risk factors for initiation during freshman year. Addict Behav. 2014;39(1):302-7. https://doi.org/10.1016/j.addbeh.2013.10.018

5. Bajwa HZ, Al-Turki ASA, Dawas AMK, Behbehani MQ, Al-Mutairi AMA, Al-Mahmoud S, et al. Prevalence and factors associated with the use of illicit substances among male university students in Kuwait. Med Princ Pract. 2013;22(5):458-63. https://doi.org/10.1159/000350609

6. Locke GW, Shilkret R, Everett JE, Petry NM. Interpersonal guilt and substance use in college students. Subst Abus. 2015;36(1):113-8. https://doi.org/10.1080/08897077.2014.885482

7. Vázquez MJP, Oviedo AD, Olalde MGC. Life experience of adolescent drug users: a phenomenological approach. Rev Esc Enfermagem USP. 2018;52:e03349. https://doi.org/10.1590/s1980-220x2017042803349

8. Arria AM, Garnier-Dykstra LM, Cook ET, Caldeira KM, Vincent KB, Baron RA, et al. Drug use patterns in young adulthood and post-college employment. Drug Alcohol Depend. 2013;127(1-3):23-30. https://doi.org/10.1016/j.drugalcdep.2012.06.001

9. Johnston LD, O'Malley PM, Bachman JG, Schulenberg JE. Monitoring the Future: national survey results on drug use, 1975-2008. Vol. II, College students and adults ages 19-50 Bethesda, MD: National Institute on Drug Abuse; 2010. (NIH Publication No. 09-7403).

10. Substance Abuse and Mental Health Services Administration. Results from the 2008 National Survey on Drug Use and Health: national findings. Rockville, MD: Office of Applied Studies; 2009. (NSDUH Series H-36, HHS Publication No. SMA 09-4434).

11. Andrade AG, Duarte PCAV, Oliveira LG, organizadores. I Levantamento Nacional sobre o Uso de Álcool, Tabaco e outras Drogas entre Universitários das 27 Capitais Brasileiras. Brasília, DF: Secretaria Nacional de Políticas sobre Drogas; 2010.

12. Andrade AG, Duarte PCAV, Barroso LP, Nishimura R, Alberghini DG, Oliveira LG. Use of alcohol and other drugs among Brazilian college students: effects of gender and age. Rev Bras Psiquiatr. 2012;34(3):294-305. https://doi.org/10.1016/j.rbp.2012.02.002 
13. Canuto MHA, Ferreira RA, Guimarães EMB. Uso e abuso de drogas ilícitas por jovens do $1^{\circ}$ ano da Universidade Federal de Goiás. Rev Paul Pediatr. 2006;24(2):135-42.

14. Kracmoravá L, Klusonová H, Petrelli F, Grappasonni. Tobacco, alcohol and illegal substances: experiences and attitudes among Italian university students. Rev Assoc Med Bras. 2011;57(5):523-8. https://doi.org/10.1590/S0104-42302011000500009

15. Dhanookdhary AM, Gomes AM, Singh N, Khan R, Lall A, Murray D, et al. Substance use among university students at the St Augustine Campus of the University of the West Indies. West Indian Med J. 2010;59(6):641-9.

16. Silva LVER, Malbergier A, Stempliuk VA, Andrade AG. Fatores associados ao consumo de álcool e drogas entre estudantes universitários. Rev Saude Publica. 2006;40(2):280-8. https://doi.org/10.1590/S0034-89102006000200014

17. Beebe LA, Vesely SK, Oman RF, Tolma E, Aspy CB, Rodine S. Protective assets for non-use of alcohol, tobacco, and other drugs among urban American Indian youth in Oklahoma. Matern Child Health J. 2008;12 Suppl 1:S82-90. https://doi.org/10.1007/s10995-008-0325-5

18. Heavyrunner-Rioux AR, Hollist DR. Community, family, and peer influences on alcohol, marijuana, and illicit drug use among a sample of Native American youth: an analysis of predictive factors. J Ethn Subst Abus. 2010;9(4):260-83. https://doi.org/10.1080/15332640.2010.522893

19. Martin CS. Timing of alcohol and other drug use. Alcohol Res Health. 2008;31(2):96-9.

20. Pilatti A, Caneto F, Garimaldi JA, Vera BV, Pautassi RM. Contribution of time of drinking onset and family history of alcohol problems in alcohol and drug use behaviors in Argentinean college students. Alcohol Alcohol. 2013;49(2):128-37. https://doi.org/10.1093/alcalc/agt176

21. Bustamante IV, Carvalho AMP, Oliveira EB, Oliveira Júnior HP, Figueroa SDS, Montoya Vásquez $\mathrm{E}$, et al. University students' perceived norms of peers and drug use: a multicentric study in five Latin American countries. Rev Latinoam Enfermagem. 2009;17 N Espe:838-43. https://doi.org/10.1590/S0104-11692009000700013

22. Antoniassi Júnior G, Gaya CM. Implicações do uso de álcool, tabaco e outras drogas na vida do universitário. Rev Bras Promoç Saude. 2015;28(1):67-74. https://doi.org/10.5020/18061230.2015.p67

23. Passos SRL, Americano do Brasil PEA, Santos MAB, Aquino MTC. Prevalence of psychoactive drug use among medical students in Rio de Janeiro. Soc Psychiatry Psychiatr Epidemiol. 2006;41(12):989-96. https://doi.org/10.1007/s00127-006-0114-7

24. Harris PA, Taylor R, Thielke R, Payne J, Gonzalez N, Conde JG. Research Electronic Data Capture (REDCap): a metadata-driven methodology and workflow process for providing translational research informatics support. J Biomed Inform. 2009;42(2):377-81. https://doi.org/10.1016/j.jbi.2008.08.010

25. Laranjeira R, supervisor, Madruga CS, Pinsky I, Caetano R, Mitsuhiero SS, Castello G. II Levantamento Nacional de Álcool e Drogas (LENAD). São Paulo: Instituto Nacional de Ciência e Tecnologia para Políticas Públicas de Álcool e Outras Drogas (INPAD); UNIFESP; 2014.

26. Pilli L, coordenador, Suzzara B, Alves M, Reis M, Yamakawa P, Nunes R, et al. Criterio de classificação econômica-2015. São Paulo: Associação Brasileira de Empresas de Pesquisa (ABEP); 2016.

27. Santos IS, Tavares BF, Munhoz TN, Almeida LSP, Silva NTB, Tams BD, et al. Sensibilidade e especificidade do Patient Health Questionnaire-9 (PHQ-9) entre adultos da população geral. Cad Saude Publica. 2013;29(8):1533-43. https://doi.org/10.1590/0102-311X00144612

28. Teixeira RF, Souza RS, Buaiz V, Siqueira MM. Uso de substâncias psicoativas entre estudantes de odontologia da Universidade Federal do Espírito Santo. Cienc Saude Coletiva. 2010;15(3):65562. https://doi.org/10.1590/S1413-81232010000300007

29. López-Quintero C, Pérez de los Cobos J, Hasin DS, Okuda M, Wang S, Grant BF, et al. Probability and predictors of transition from first use to dependence on nicotine, alcohol, cannabis, and cocaine: results of the National Epidemiologic Survey on Alcohol and Related Conditions (NESARC). Drug Alcohol Depend. 2011;115(1-2):120-30. https://doi.org/10.1016/j.drugalcdep.2010.11.004

30. Chen $\mathrm{CY}$, Storr $\mathrm{CL}$, Aanthony JC. Early-onset drug use and risk for drug dependence problems. Addict Behav. 2009;34(3):319-22. https://doi.org/10.1016/j.addbeh.2008.10.021

31. Center for Behavioral Health Statistics and Quality. Results from the 2012 National Survey on Drug Use and Health: summary of national findings Rockville, MD: Substance Abuse and Mental Health Services Administration; 2013. (HHS Publication No. SMA 13-4795, NSDUH Series H-46). 
32. Polymerou A. Alcohol and drug prevention in colleges and universities: a review of the literature. London: Mentor UK; 2007.

33. Kauffman SE, Silver P, Poulin J. Gender differences in attitudes toward alcohol, tobacco, and other drugs. Soc Work. 1997;42(3):231-41. https://doi.org/10.1093/sw/42.3.231

34. Schwartz JB. The influence of sex on pharmacokinetics. Clin Pharmacokinet. 2003;42(2):107-21. https://doi.org/10.2165/00003088-200342020-00001

35. McCabe SE, Morales M, Cranford JA, Delva J, McPherson MD, Boyd CJ. Race/ethnicity and gender differences in drug use and abuse among college students. J Ethn Subst Abus. 2007;6(2):75-95. https://doi.org/10.1300/J233v06n02_06

36. Laranjeira R, Pinsky I, Zaleski M, Caetano R, Duarte PCAV. Levantamento Nacional sobre os Padrões de Consumo de Álcool na População Brasileira. Brasília, DF: Secretaria Nacional de Políticas sobre Drogas; 2007.

37. Johnston LD, O'Malley PM, Bachman JG, Schulenberg JE. Monitoring the Future National Survey Results on Drug Use, 1975-2004. Volume II: College Students \& Adults Ages 19-45. Bethesda, MD: National Institute on Drug Abuse; 2005. (NIHPublication 05-5728).

38. Chen K, Kandel DB. Predictors of cessation of marijuana use: an event history analysis. Drug Alcohol Depend. 1998;50(2):109-21. https://doi.org/10.1016/S0376-8716(98)00021-0

39. Duncan GJ, Wilkerson B, England P. Cleaning up their act: the effects of marriage and cohabitation on licit and illicit drug use. Demography. 2006;43(4):691-710. https://doi.org/10.1353/dem.2006.0032

40. Humensky JL. Are adolescents with high socioeconomic status more likely to engage in alcohol and illicit drug use in early adulthood? Subst Abus Treat Prev Policy. 2010;5:19. https://doi.org/10.1186/1747-597X-5-19

41. Farrell S, Manning WG, Finch M. Alcohol dependence and the price of alcoholic beverages. J Health Econ 2003;22(1):117-47. https://doi.org/10.1016/S0167-6296(02)00099-1

42. Baus J, Kupek E, Pires M. Prevalência e fatores de risco relacionados ao uso de drogas entre escolares. Rev Saude Publica. 2002;36(1):40-6. https://doi.org/10.1590/S0034-89102002000100007

43. Larzelere RE, Patterson GR. Parental management: mediator of the effect of socioeconomic status on early delinquency. Criminology. 1990;28(2):301-24. https://doi.org/10.1111/j.1745-9125.1990.tb01327.x

44. Martins SS, Storr CL, Alexandre PK, Chilcoat HD. Adolescent ecstasy and other drug use in the National Survey of Parents and Youth: the role of sensation seeking, parental monitoring and peer's drug use. Addict Behav. 2008;33(7):919-33. https://doi.org/10.1016/j.addbeh.2008.02.010

45. Armstrong EA, Hamilton LT. Paying for the party: how college maintains inequality. Cambridge, MA: Harvard University Press; 2013.

Funding: This study was financed in part by the Coordenação de Aperfeiçoamento de Pessoal de Nível Superior - Brasil (CAPES) - Financing Code 001.

Authors' contribution: Study conception and planning: GMH, IOB, MFS. Data collection, data analysis and interpretation: GMH, IOB, BDF, MFS. Elaboration and revision of the manuscript: GMH, IOB, MFS. Approval of the final version to be published: GMH, IOB, BDF, MFS. Public responsibility for the content of the article: GMH, IOB, BDF, MFS.

Conflict of Interest: The authors declare no conflict of interest. 